\title{
Blodet på det mintgrønne papir Sanse-etnografiske analyser af materialitet i gynækologiske undersøgelser
}

\section{Af Matilde Lykkebo Petersen}

\begin{abstract}
The Blood on the Mint Green Paper. The aim of the article is to explore how materiality and bodily experience can be studied through an attention to the senses. Based on Karen Barad's conceptualization of agential realism I explore the materiality and bodily experience of gynaecological practices and egg donation through sensory ethnographic observations. My sensory experiences of the three events function as a prism to explore how material and bodily agencies co-constitute the specific phenomena at hand, and I thus offer a methodological approach to the study of gynaecological practices and egg donation which promises new analytical avenues for future ethnographic research on reproductive technologies.
\end{abstract}

\section{KEYWORDS}

methodology, sensory ethnography, feminist new materialisms, egg donation, auto-ethnography/ metodologi, sanse-etnografi, feministisk nymaterialisme, agdonation, auto-etnografi

Matilde Lykkebo Petersen er ph.d.-studerende ved Institut for Kulturvidenskaber, Syddansk Universitet. Hendes ph.d.-projekt omhandler ægdonation i Danmark og er en del af forskningsprojektet REMM Reproductive Medicine and Mobility. 


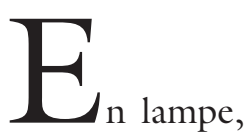

der skinner skarpt i øjnene, kolde metalinstrumenter, varme hænder, muskler, der spændes. Bip- bip- lyde og dæmpede stemmer. Lys, lyde, rumlighed, kropslighed. Materielle aspekter af specifikke frnomener, aspekter, der gør noget ved fænomenerne, som bliver fænomenet. Hvis materielle aspekter - materialiteten - kan siges at have agens, hvordan kan man så undersøge, hvad materialiteten gør? Hvordan agerer og konstituerer materialiteten sig som verden i og omkring os? I denne artikel vil jeg udforske, hvordan et afsæt i sanser og sanselighed kan anvendes til at undersøge materialitet og kropslighed. Dette eksemplificeres gennem observation af gynækologiske undersøgelsespraksisser produceret inden for en metodologisk ramme inspireret af sanse-etnografien og nymaterialistisk teori.

Interessen for sanser og forståelsen af, at en vending mod sansning er produktiv for viden om menneskers levede liv og de processer, de bliver til i, har i de seneste år bredt sig på tværs af discipliner. Eksempelvis beskæftiger sanse-etnografi (Pink 2015), sanse-antropologi (Berkaak \& Norbye 2014), og sanse-sociologi (Vannini, Waskul \& Gottschalk 2012) sig overordnet med at forstå de processer, hvori betydningsdannelse og sansning hænger sammen. Denne interesse for sanserne kan knyttes til den generelle drejning mod krop, materialitet og affekt, som i de sidste par årtier har fundet sted på tværs af akademia (Christensen \& Hauge 2012; Christiansen, Frydendahl \& Pedersen 2013) Her er den centrale tanke:

at det materielle kan virke direkte på oss uten noen symbolsk eller semantisk mediering. Det vil si at vi ikke forholder oss til verden først og fremst gjennom tenkning og tegnforhold, men fysiologisk/nevrologisk med en materiell og affektiv verden. (Berkaak \& Norbye 2014: 137).
Et fællestræk ved vendingerne mod materialitet og affekt er en interesse $i$ at komme ud over den repræsentationstankegang, som kritiseres for at klæbe til human- og socialvidenskaberne (e.g. Barad 2007; Colebrook 2010; Hultman \& Taguchi 2010), på trods af poststrukturalismens opposition imod idéen om at 'vi' konstruerer verden gennem sproget (Colebrook 2010: 154). Kritikken lyder, at hvis man antager sprog og diskurs som udgangspunkt, og mennesker anses som de eneste producenter af sprog og diskurs, bliver det menneskelig betydningsdannelse, der konstruerer kroppe, materialiteter og realiteter. På den måde fastholdes binariteter som human/non-human og diskurs/materialitet (Hultman \& Taguchi 2010; Alaimo \& Hekman 2008). Materialiteten tildeles ikke agens i produktionen af diskurs, diskursive praksisser og menneskelig subjektivitet (Hultman \& Taguchi 2010: 526). Og som Hultman og Taguchi pointerer:

This reduces our world to a social world, consisting only of humans and neglecting all other non-human forces that are at play." (Hultman \& Taguchi 2010: 526 kursiveringer i original).

I denne artikel anvender jeg den feministiske teoretiker Karen Barads teori om agentiel realisme, som er en kobling af poststrukturalistisk tankegods fra Michel Foucault og Judith Butler og Niels Bohrs kvantefysik (Barad 2007). Barad stiller sig i høj grad på skuldrene af Butlers teoretisering af kønnet materialisering, men kritiserer hende for at fokusere på "how discourse comes to matter" og ikke "how matter comes to matter" (Barad 2007: 192 kursiveringer $\mathrm{i}$ original). Barad fremskriver et rammeværk, hvor fænomener i verden forstås som materiel-diskursive - altså sammenfiltringer af materialitet og diskursivitet - som specifikke tid-rum-materialitets-kon- 
figurationer, som tilblivelser, og ikke som færdigkonstituerede essenser (Barad 2007). Barad forsøger med sin onto-epistemologi at bryde med repræsentationstankegangen, og give plads til et fokus på materialitetens agens. Med sit komplekse rammeværk demonstrerer hun, hvordan både det diskursive og det materielle har agens (og altså ikke en udelukkelse af det diskursive). Ved at tage afsæt i Barads teoretiske ramme, positionerer jeg mig således mere pragmatisk i forhold til en feministisk, poststrukturalistisk videnstradition, idet jeg anskuer fænomener som bestående af både materielle agenser og kulturelle, sociale, historiske diskurser.

En opmærksomhed på materialitetens agens - hvad for eksempel kroppe og de materielle aspekter i et givent fænomen gør - åbner som udgangspunkt op for spørgsmål om, hvordan denne materialitet i så fald kan undersøges. Inspireret af Barad's opmærksomhed på "how matter makes itself felt” (Barad 2007: 66) vil jeg i denne artikel udforske en metodologisk tilgang til at undersøge, hvordan og hvad materialiteten gør i fænomenet. For at undersøge dette vender jeg blikket mod sanse-etnografien.

\section{SANSER, MATERIALITET OG \\ REPRODUKTIONSTEKNOLOGI}

At arbejde sanse-etnografisk er en måde at arbejde aktivt med både forsker- og deltagersubjektets kropslige perception af et fænomen. Ifølge Vannini et al. er al etnografisk arbejde potentielt sanse-etnografi det er et spørgsmål om at være refleksiv og sensitiv og om en tilgang til at skærpe opmærksomheden på noget uvant (Vannini, Waskul \& Gottschalk 2012:69). Det er en undersøgelsesstrategi, der forsøger at overskride binariteter som sind/krop, eller dét at sanserne kan opdeles i en kognitiv og en fysisk del (Vannini, Waskul \& Gottschalk 2012: 12). Tilgangen flytter ifølge Vannini et al. fokus fra 'essens' til 'aktivitet', idet den sanselige perception konceptualiseres som en kropslig-kognitiv proces. For hvad er sanser for en størrelse? Sansning er noget vi gor og oplever i relation til vores omgivelser, noget der kan bringe følelser og fornemmelser frem hos os, altså et kropsligt og materielt fænomen, der artikulerer spørgsmål om, hvordan det kropslige og det kognitive hænger sammen i menneskelig betydningsdannelse. De fleste kender fra deres børnelærdom de fem sanser - høre, se, lugte, føle og smage. Som Vannini et al. lister op, er der derudover sanser, der, i modsætning til de fem, giver information om den ydre verden omkring os, giver information inde fra menneskekroppen: smertesansen, tørst og sult, sansning af vores indre muskler og organer, samt de sanser, der medierer information mellem det indre og det ydre såsom balancesansen, bevægelse, temperatur og tidsfornemmelse (Vannini, Waskul \& Gottschalk 2012: 6). I sansningen af et fænomen gør kroppen noget og denne agens (gøren) er en form for kropslig-materiel viden. I tråd med agentiel realisme og forståelsen af fænomener som materiel-diskursive tilblivelser, forstår jeg her kropslighed og sanselighed som en form for betydningsskabende viden og agens $i$ et fænomen. Det er den kropslige perception og involvering $i$ et fænomen, som jeg i denne artikel vil undersøge for derved at demonstrere mulighederne for at situere et andet blik på materialitet.

For at udforske dette andet blik på materialitet og kropslighed analyserer jeg observationer fra den klinisk gynækologiske praksis, der relaterer sig til et igangværende studie af xgdonorers oplevelser og erfaringer. Jeg vil gennemgå tre begivenheder, der er produceret gennem sanse-etnografisk observation. Begivenhed et trækker på observationer fra to ultralydsscanninger $i$ et xgdonationsforløb med én af mine informanter. Begivenhed to er en auto-etnografisk sanse-observation i forbindelse med et gynækologbesøg i september 2015. Begivenhed tre er en observation af xgudtagningen i samme xgdonationsforløb som den første begivenhed. ${ }^{1}$ 
Jeg knytter altså en baradsk optik til en auto- og sanse-etnografisk tilgang på baggrund af den onto-epistemologiske pointe at 'observationsagenter og -objekter' kan forstås som en intra-aktiv praksis, som én og samme ting. Denne pointe er en videreudvikling af Donna Haraways situated knowledges (Haraway 1988), hvor hun videreudvikler Sandra Hardings begreb om strong objectivity (Harding 1986). Barads etiko-onto-epistemologi er en radikal gentænkning af et objektivitetskriterium produceret gennem et etisk ansvarligt forskersubjekt, der bliver til i det undersøgte fænomen. Den auto-etnografiske tilgang inddrager konkret forskersubjektets emplacement (Pink 2015) i frnomenet som en del af det empiriske materiale. Jeg vil bruge begivenhed et til at demonstrere, hvordan $\mathrm{Ba}-$ rads begreber kan anvendes til at anskue gynækologiske praksisser som fænomener bestående af diskursive og materielle agenser. Ved hjælp af begivenhed to og tre diskuterer jeg, hvordan materialitet kan undersøges gennem en forståelse af sanselighed som betydningsskabende agens.

Auto-etnografisk sanse-observation anvendes af flere grunde. Først og fremmest fokuserer en sanse-etnografisk tilgang på forskerens egen sensibilitet for dermed at engagere forskersubjektet som emplaced og embodied subjekt i forskningen (Pink 2015). Ifølge Sarah Pink kan en sanse-etnografisk erkendelsesinteresse groft inddeles i to kategorier. Den første er en mere klassisk antropologisk tilgang, der, gennem et etnografisk studie, ser på systemer af sanse-kategoriseringer og klassificeringer i det sociale liv, og på hvordan mening relateres til disse. Den anden situerede (emplaced) tilgang tager derimod udgangspunkt i den selvrefleksive og erfarende krop. Her er udgangspunktet ikke en interesse i systematisk at undersøge sansekategorier og 'kultur', men at bruge etnografens egen sanseoplevelse til at forstå andre menneskers oplevelser, måder at erkende, og sansekategorier, -betydninger og -praksisser (Pink 2015:
27). Selve tilgangen som 'embodied' etnograf er dét, der, ifølge Pink, producerer ny viden om menneskelig perception, erfaring, handling og betydningsdannelse (Pink 2015: 54).

Min forskning er dog også en del af et eksisterende forskningsfelt, som har rejst en række diskussioner inden for feministiske studier, særligt i forhold til spørgsmål om, hvilken betydning reproduktionsteknologier har for globale og lokale magtrelationer, og hvordan køn, race, klasse, alder og slægtsskab spiller sammen i disse relationer (Gammeltoft \& Wahlberg 2014). Derudover har denne forskning også interesseret sig for, hvordan reproduktionsteknologi transformerer den kvindelige reproduktive krop og hvordan dette udfordrer traditionelle feministiske idealer om kvindens selvbestemmelse over hendes egen krop (Gupta \& Richters 2008). Størstedelen af disse studier har et antropologisk udgangspunkt og bruger derfor primært etnografiske metoder (Inhorn \& Gürtin 2011: 667).

Centrale tematikker i feltet er eksempelvis ægdonorernes motivationer og de kønnede diskurser omkring xgdonation relateret til altruisme og moderskab (Curtis 2010), det transnationale marked, hvor (kønnede) diskurser om kropsligt ejerskab og frivillighed er i spil (Nahman 2008) og kommercialisering af kroppen (Almeling 2011). Jeg har en særlig interesse i den måde, hvorpå kropslighed og materialitet er på spil i feltet xgdonation. Et eksempel herpå er René Almelings studie fra 2011, hvor hun undersøger kropslig markedsliggørelse (for både $x g-$ og sæddonation), og bl.a. har fokus på materialitet i form af den bioteknologiske udvikling og hvordan donorernes kropslige involvering i markedet struktureres gennem bestemte kønnede og økonomiske normer (Almeling 2011: 13). Materialitet er her et vægtigt aspekt, men fremskrives ikke som teoretisk fokuspunkt. Stine Adrians afhandling om xg- og sæddonation fra 2006 har derimod et eksplicit afsæt i feministisk nymaterialistisk teori 
(Barad og Haraway) og dét at materialiteten har agens (Adrian 2006:9). Dette etnografiske studie undersøger, hvordan specifikke diskurser, normer og betydninger er koblet til de materiel-diskursive knudepunkter: $æ g$, sæd og embryoner (Adrian 2006: 17). Ligeledes er der i Michal Nahman's studie af, hvordan reproduktionsteknologier i Israel er knyttet til ideer om nationen (Nahman 2013), et særligt fokus på materialitet som et centralt aspekt af den sammenfiltring af praksisser, som producerer reproduktionsteknologier. Hun rammesætter ægudtagning således:

“Oocyte extractions are discursive practices (Butler, 1993), sets of actions and ways of speaking about the world that bring them into being. They are material-semiotic generative nodes (Haraway 1997), matter and meaning at once, which are enacted or brought into being (Mol 2002). To separate them out from all the aspects that materialize them would be to deny how things are made through multiple entanglements (Barad 2007).”

(Nahman 2013: 11)

Således peger flere af studierne på en materialistisk teoretisk tilgang som vigtig (Leve 2013; Roberts 2012; Nahman 2013; Adrian 2006). Jeg knytter $i$ denne artikel således an til denne forskning, med sit udgangspunkt i nymaterialistisk teori, og vil, ved at anvende sanse-etnografiske undersøgelsesstrategier, bidrage med nye perspektiver på, hvordan materialitet og kropslighed i ægdonation kan undersøges.

\section{BEGIVENHED 1: UltRALYDSSCANNING}

\section{Scanning efter 5 dage på hormoner.}

Der kommer køligt, hvidt dagslys ind gennem vinduet, hvor persiennerne står åbne. Linoleumsgulvet er lysegråt, og møblementet herinde er robust, lyst lakeret træ, stål og plastik. Institutions-agtigt. Mens jeg spørger lægen om noget, lægger Anne sig op i gynækolog-stolen. Jeg sidder på hendes venstre side, og lægen sidder ved benenden med en ultralydsscanner. "Det er iskoldt det her" siger lægen, og fører scanneren op i Annes skede. Scanningsbilledet viser efter lidt justeringer fra lægen en grå ubestemmelig masse. Annes livmoder. Der er stille lidt tid, mens lægen kigger og koncentrerer sig. "Se den smukke grå-pære som ligger helt stille her. Din slimhinde er begyndt at blive 3-laget". Lægen flytter scanneren til siderne og ser omrids af xggestokke med ægblærerne i. "Nydeligt. Så flot".

På scannerens monitor er der billede i sort/ hvid/grå af noget der må være omridset af en xggestok, hvor der er nogle sorte runde pletter, som er ægblærerne. De er fyldt med væske. Hun tæller de sorte klatter, 5 i den ene side. Så begynder hun at måle dem, ved at tegne krydser over dem med musen på skærmen.

Bip-

Bip-

Scanneren siger svage bip-lyde mens maskinen måler. Den største er $13 \mathrm{~mm}$. "Du skal starte med hæmmeren i dag. De kan begynde at overveje at sende ægløsningssignal.” ...

\section{Sidste scanning inden agudtagning.}

"Jeg vil sige, at jeg har det, som om jeg er fyldt ud", svarer Anne til lægens spørgsmål om, hvordan hun har det. Hun skal scannes igen for at se, hvor store ægblærerne er blevet så ægudtagningen kan planlægges.

Med ultralydsscanneren kigger lægen på Annes livmoder og xggestokke.

Stilhed

afløst af Bip - bip -

Annes slimhinde er ikke så tyk, $6 \mathrm{~mm}$, men bare den er over 5 er det $\mathrm{OK}$, siger lægen. På monitoren er der sort-hvide-grå konturer og flimmer. " $1-2-3-4-5-$ på den her side". Lægen tæller ægblærerne, der ligger som sorte poser i hver af de to æggestokke.

Bip-lyde. Hun måler ægblærerne med musen. Den måler $14 \mathrm{~mm}$. På monitoren vi kan se er den nok ca. $4 \mathrm{~cm}$.

VUUUP 
Scanneren siger en summende lyd, lægen har skiftet over til den anden side. Anne siger, den er mere $ø \mathrm{~m}$.

Stille.

Bip - bip -

I den side måtte æggestokken holdes fast med en tang sidste gang, hun fik taget $x g$ ud.

$\ldots$

Ovenstående er et uddrag af mine observationer af, hvordan Anne bliver scannet som en del af hendes forløb som xgdonor. Hun donerer xg til et barnløst par, og jeg har observeret besøgene på klinikken og interviewet Anne om hendes oplevelse af at være xgdonor. Det er anden gang Anne donerer $\mathfrak{x g}$, og ligesom første gang har hun valgt at finde et modtagerpar på egen hånd gennem en gruppe på Facebook. Forløbet har på denne klinik bestået af en indledende konsultation med scanning og diverse prøver, som finder sted på menstruationens 2. dag. Her påbegyndes hormonbehandlingen, som består i, at Anne giver sig selv en hormonindsprøjtning i maveskindet en gang om dagen. Herefter en ny scanning på klinikken 5 dage efter for at se, hvordan $x g$ blærerne har udviklet sig. Herefter er Anne blevet scannet en gang mere, på 8. hormonbehandlingsdag, for at kunne fastlægge xgudtagningen. Ægudtagningen fandt i dette tilfælde sted på 11. dag efter påbegyndt hormonbehandling.

I den følgende baradske analyse af observationen af ultralydsscanningen har jeg rettet min opmærksomhed på de tre hovedaktører i begivenheden: Annes underliv, lægens scanner-ekspertise og monitorens billedvisning. Disse tre aktører intra-agerer (Barad 2007), og i observationen afgrænses et fænomen, der kan defineres som en ultralydsscanning. ${ }^{2}$

Når lægen bevæger scanneren i Annes skede, ved hun, hvordan hun skal betjene scanner-apparatets teknologi for at vise og tolke dét, som scanneren intra-agerer med; nemlig Annes underliv. Annes underliv skedevæg, livmoder, xggestokke med $x$ - blærer - intra-agerer med scanneren og lægen og producerer monitorens film: sort/ hvide konturer af indre organisk væv, der i begivenheden sprogligt beskrives ud fra lægens tolkning ("Se den smukke grå-pære som ligger helt stille her"). Lægen "tegner streger som et kryds med musen over en af de sorte blærer”, altså på Annes æggestokke, der vises på monitoren og som produceres digitalt gennem scanningen. Annes, lægens og mine egne øjne er rettet mod monitoren, hvor vi oplever, at æggestokkene (også) befinder sig, og accepterer umiddelbart den visuelle forlængelse af æggestokkene. For Anne og jeg selv er monitorens billeder svære at forstå, og det er derfor lægens konkrete afgrænsninger ved hjælp af sproglige anvisninger og streger med musen, der definerer, hvad der etableres som hhv. 'ægblære', 'livmoder', 'æggestok' og 'slimhinde'. Mens xgblærerne 'blopper' frem på skærmen bliver de ved lægens (og scannerens) produktion til som materielt-diskursive fanomener (Barad 2007:153).

Intra-aktion og materielt-diskursiot fenomen er centrale begreber hos Barad. Når jeg anskuer ultralydsscanningen med Barads begrebsapparat hjælper det til at forstå, hvordan kroppens biologi, den medicinske teknologi og det sprogligt-diskursive er filtret sammen, og hvordan disse aspekter agerer $\mathrm{i}$ og med hinanden i en dynamisk intra-aktivitet.

Det er således ikke monitoren, der 'viser noget' - i en baradsk optik er det monitoren, der, som en del af scanningsapparatets intra-aktion med kvindens livmoder, producerer noget. Hvad man i en traditionel forståelse af visuelle medier (såsom monitorskærmen) vil anskue som en representation af kvindens underliv, er i denne optik ikke en repræsentation, men en produktion. Monitoren 'repræsenterer' ikke æggestokke og xgblærer, den er æggestokke og ægblærer i det specifikke fænomen 'ultralydsscanning' i denne begivenhed. Æggestokkene 'forlænges' visuelt og teknologisk i ultralyds- 
scanningen (forlænges fra dét, man sædvanligvis betragter som xggestokke, nemlig noget organisk, biologisk væv inde i en menneskekrop), og skaber en ny afgrænsning for fænomenet, nemlig 'ultralydsscannede rggestokke'.

Samtidig er de forskellige teknologiske, kropslige, sanselige aspekter med til at afgrænse og konstituere situationen som en kropslig oplevelse på en bestemt måde. Indføringen af den 'iskolde scanner' markerer en grænse mellem Annes varme krop og scannerapparatet. Men i samme bevægelse som denne afgrænsning markeres, overskrides den og etableres i en ny afgrænsning: underlivets forlængelse i monitoren. Bipbip lydene bliver et orienteringspunkt for den kropslige-teknologiske konstellation, som Anne nu indgår i, og danner en betydningsramme for den kropslige oplevelse af scannerens bevægelser inde i hende. Scanneren agerer sammen med Annes krop ved at sige lyde - som det lange VUUUP, når den skifter side og afgrænser begge sider af underlivet. De sansede indtryk spiller ganske bestemte roller i konstitueringen af scanningsoplevelsen. Fokus på disse få sanselige aspekter tydeliggør, hvordan en specifik kropslighed afgrænses og etableres gennem materielle, kropslige aspekter i fænomenet.

\section{BEGIVENHED 2: GYNÆKOLOGBESØGET}

Jeg går om bag forhænget og tager mine strømpebukser og trusser af. Jeg plejer altid at have kjole på til de her ting. Luften i rummet føles anderledes på de bare ben. Jeg går med bare tæer hen over gulvet og sætter mig op i gynækologstolen. Jeg lægger mig ned, min krop føles varm indeni og kold udenpå, og jeg kan smage mine tænder. Jeg har en svag skrumpende fornemmelse i hjernen, som den type hovedpine plejer at føles. Jeg er meget opmærksom og prøver at få mine muskler til at afspænde og vejrtrækning til at blive rolig. Hun beder mig lægge hænderne på nederste del af maven og presse. Undersøgelsen star- ter. Hun sætter forsigtigt røret op og begynder at kigge. "Det ser fint ud, ikke noget suspekt”, som hun siger. Mit hjerte slår hurtigt og mod min vilje spænder jeg over det hele, jeg prøver at trække vejret dybt og slappe af. Det sitrer i min ene baldemuskel og jeg retter min opmærksomhed mod at slappe den af også.

"Nu kommer der lige to små prik" siger hun. "Kan du lige hoste lidt?" Jeg hoster. Det prikker i livmoderhalsen da jeg med mit host făr presset bækkenet ned. Det gør ondt. "En gang til”. Jeg hoster igen. Min krop føles som om den kun består af hjerne, torso og underliv. Arme og ben er nogle underligt afkoblede, blodløse stængler.

$\mathrm{Nu}$ er jeg lokalbedøvet. "Jeg starter lige med at tage nogle skrab, det er det værste" siger hun.

Imens spørger hun ind til mit arbejde. Jeg tænker bare på at trække vejret og slappe af og få min stemme til at slappe af. Jeg ved faktisk ikke rigtig, hvad jeg siger til hende.

$\mathrm{Nu}$ er hun kommet til biopsierne. Det føles som om hun spænder mig ud indvendigt og sætter klemmer på. Der kommer nogle spænd og klik, som om hun niver i mig. Det er en helt uvant følelse. Hvad end det er, hun hiver i, inden i mig, så er det tilsyneladende ret stærkt. Hun sidder med nogle små prøveglas, som hun samler med prøverne fra mig.

Jeg fryser ikke, men har alligevel følelsen af at min bare hud på lårene bliver afkølet i rummet. Det papirunderlag jeg ligger på er svagt mintgrønt, tyndt og stift. Jeg synes det har en hospitalsagtig farve. Eller som den hagesmæk man får på hos tandlægen. Gynækologen har en pandelampe på. Lyset i rummet er behageligt dæmpet, det er kun lampen over gynækologstolen, en arbejdslampe ved et bord henne ved væggen og gynækologens pandelampe, der har et mere kraftigt hvidt skær. Selvom jeg synes det er ubehageligt, så føler jeg mig tryg i rummet. Hun afslutter undersøgelsen med at stoppe noget gaze op på grund af blødning. Hun tager røret ud og jeg kan sætte mig op. Jeg bliver overrasket over at se frisk rødt blod på det mintgrønne papir. 
Ovenstående er en sanse-etnografisk observation fra et besøg på en gynækologisk klinik, hvor jeg i september 2015 fik taget prøver for celleforandringer i livmoderhalsen. Selvom dette besøg ikke er relateret til xgdonation, så er der en fælles erfaring på spil i forhold til den gynækologiske undersøgelsespraksis. En måde at arbejde med sanse-etnografi er i første omgang at skærpe sin opmærksomhed på egen sanse-aktivitet $\mathrm{i}$ en given kontekst - gerne en relativt uvant kontekst, da opmærksomheden her ofte er høj og ikke præget af vane (Vannini, Waskul, \& Gottschalk 2012: 68). En gynækologisk undersøgelse er ikke den samme vante sanseoplevelse som at spise eller at gå i bad, men en oplevelse, der skærper sanserne gennem den uvante kontekst. Det er en praksis, hvor jeg som forskersubjekt forholder mig til en sanseoplevelse, der har lighedspunkter med xgdonorernes i forhold til opmærksomhedspunkter i kroppen, og mødet mellem min krop og en klinisk praksis.

De forskellige sanseindtryk konstituerer en specifik kropslig oplevelse, en konstellation af forskellige sammenfiltrede (entangled) sanser. Oplevelsen af kølig luft og varm krop der mødes, producerer en kropslig bevidsthed om en grænse - en grænse, der skal til at blive overskredet. Her bliver sansningen af kølig luft på den bare hud en markering af en kropslig grænseflade i mødet med gynækologpraksissen. Muskelspændinger og vejrtrækning, der har svært ved at blive rolig, producerer oplevelsen af en specifik, uvant situation (gynækologundersøgelsen) og markerer en negativ, nervøs forventning. Fokus flyttes fra underlivet til den sitrende baldemuskel, som på den måde aktiverer en oplevelse af en autonom, delvist uregerlig, kropslighed, som skal blive til en bestemt krop (en rolig, arbejdsvillig krop) idet den skal underlægges den gynækologiske undersøgelse og prøvetagning. I situationen konstitueres min krop som en autonom, levende organisme, en krop-underkastet-kontrol/krop-ude-af-kontrol grænseflade. Fornemmelsen af at være meget 'til stede' i den kropslige oplevelse (at arme og ben føles afkoblede, men resten af kroppen meget present) og fornemmelsen af uvante sanseindtryk af de spænd og klik i min livmoderhals, lægen udfører, producerer oplevelsen af en specifik kropslighed en specifik krop-i-gynækologisk-unders $\varnothing$ gelse.

Refleksionen over den sanselige oplevelse kan begrebsliggøres med Vannini et al.'s koncept somatisk arbejde (Vannini, Waskul, \& Gottschalk 2012: 17). Her konceptualiseres sansning som konstitueret af både fysiske og kognitive elementer i intra-aktion. Somatisk arbejde er en betydningsskabende praksis, hvor kropslige handlinger og interaktioner involveres $i$ “(...) linguistical and alinguistical reflexive experiences and activities by which individuals interpret, create, extinguish, maintain, interrupt, and/or communicate somatic sensations" (Vannini, Waskul \& Gottschalk 2012: 19).

Med andre ord er refleksionen (og kommunikationen) af en sanseoplevelse - det somatiske arbejde - en automatiseret proces. I nedskrivningen af sanseoplevelsen bliver det somatiske arbejde tydeliggjort som en sproglig og ikke-sproglig aktivitet, hvor sanselige indtryk indgår $\mathrm{i}$ en kontinuerlig oplevelse af the embodied self. (Vannini, Waskul \& Gottschalk 2012: 85) Det er en oplevelse af, at den sanselige oplevelse eksisterer i en ikke-sproglig form, som alligevel er tilgxngelig for min bevidsthed. Dét at beskrive, hvordan de forskellige indtryk føles og opleves, er svært på trods af, at jeg, efter besøget, har en helt klar erindring af sansningerne i min krop og i øvrigt ikke føler det svært at skrive generelt. Ved at forstå mine sanselige oplevelser gennem Vannini et al's koncept åbner der sig en mulighed for at forstå den kropslige intra-ageren som en betydningsskabende agens. Den kropslige (og sanselige) oplevelse er således medkonstituerende for det specifikke fænomens diskursive betydning.

Den auto-etnografiske observation frem- 
bringer på denne måde også en række refleksioner, som er relevante for at forstå de oplevelser, som xgdonorer kunne have, blandt andet en opmærksomhed på de forskellige kropslige og sanselige reaktioner og egenskaber såsom kropslig hukommelse, et fokus på kontekstafhængig sanselighed og en ændring af oplevelsen over tid, en skærpet sanselighed og følsomhed, og ikke mindst bevidstheden om at følelser er knyttet til bestemte kropslige oplevelser. Disse refleksioner er muligvis som sådan ikke nye eller overraskende, men noget, som jeg som forsker alligevel kun har kunnet forstå gennem min egen kropslige og sanselige oplevelse.

I det følgende vender jeg blikket mod begivenhed tre, som er en sanse-etnografisk observation af xgudtagningen hos Anne. Her vil jeg diskutere hvordan min egen sanselige oplevelse giver viden om materialitet i det observerede fænomen.

\section{Begivenhed 3: Ægudtagning}

I midten af operationsstuen er gynækologstolen. Endevæggen er et stort vindue med persienner, som er åbne. Her er meget lyst.

Rundt om gynækologstolen står stole, et rullebord, ultralydsscanneren. Der er en monitor lige ved stolen og én på væggen overfor, så man kan følge med fra stolen også. Plastik, linoleum, stål. I hjørnet er der en dør ind til laboratoriet, der står åben. Anne lægger sig op i stolen, hun er nøgen fra maven og ned. Til stede i rummet er en læge, en sygeplejerske, en anden sygeplejerske og laboranten - alle kvinder - samt jeg selv og Anne. Gennem venflon i Annes hånd får hun det første skud morfin. Lægen går uden videre $\mathrm{i}$ gang med at lægge lokalbedøvelse i Annes skede. Den anden sygeplejerske gør en lyserød væske klar i en petriskål og nogle plastiksprøjter imens. Jeg tænker på, om Anne fryser som hun ligger dér, helt blottet.

Jeg sidder på hendes venstre side, sygeplejersken står på højre side. Med ultralydsscanne- ren leder lægen efter højre æggestok, vi kan se på monitoren hvordan væv og xgblærer skubbes rundt og i sin elasticitet undviger at ligge fast til indgrebet. Sygeplejersken lægger hænderne på det nederste af Annes mave og presser langsomt nedad. Æggestokken skubbes i position, og xgudtagningen kan begynde. Sygeplejersken holder et fast, konstant pres. På monitoren ser vi, da lægen stikker en nål ind i den første ægblære og suger væsken ud. Den sorte klat forsvinder, og der kommer et lille hvidt flimmer bagefter. Sådan fortsætter hun stille og roligt, nålen ind i næste sorte klat og suger. Værsken bliver opsamlet i det lyserøde medie i petriskålen. Herfra bliver det videregivet til laboranten inde ved siden af. Lægen fortsætter og tømmer alle de store xgblærer. Laboranten råber at der er fundet to $x g$ i første sending. Anne ligger helt stille. ...

Så skifter lægen til venstre æggestok. Her må sygeplejersken over i min side for at presse xggestokken frem, og må op at stå på en skammel for at trykke hårdt nok ned på Annes mave, fordi æggestokken ligger skjult. Det var den, der måtte holdes med tang sidst. Men nu går det fint, og lægen fortsætter tømningen af de sorte klatter på monitorskærmen.

$\ldots$

Da lægen er færdig får Anne lov at sætte sig op og sunde sig. Hun har kun fået ét skud morfin, og siger hun har det fint. Bagefter ude på gangen får Anne og jeg et glas rød saft. Det smager af sukker og solbær og er meget læskende.

Dette er et specifikt eksempel på, hvordan en xgudtagning kan forløbe. Den overordnede procedure er den samme, men ikke alles æggestokke skal have et udefrakommende pres, som Annes skal, og ikke alle er så stille som Anne. Nogle oplever meget smerte, mens andre, som Anne fortalte mig bagefter, kun mærker lidt niv og ubehag. Nogle får flere skud morfin, andre slet ikke noget. Jeg spekulerer over, hvordan det føles indeni Anne, og at jeg i nedskrivningen 
af mine oplevelser faktisk har en kropslig erindring om den (oplevede) fornemmelse jeg havde af at 'være inde i Annes krop'. Det er følelsen, eller forestillingen om følelsen, en kropslig og sanselig viden, der aktiveres i mig. I forlængelse af den tidligere beskrevne embodied ethnography, bruges min kropslige erfaring altså som integreret vidensproducerende del af det undersøgte felt.

I den specifikke situation har de forskellige sanselige og kropslige aspekter betydning for konstitueringen af det specifikke fænomen 'xgudtagning' og for Annes oplevelse af det, og er dermed en del af dét at være og at gøre xgdonor. Centralt står Annes krop, sygeplejerskens pres med hænderne, lægens håndværk med scanneren og nålen, og scannerens billeder på monitoren, der, som beskrevet ved begivenhed et, kan forstås som en forlængelse af Annes krop. Hele denne sammenfiltrede intra-aktion af aktører producerer et xgudtagningsapparat, som specifikt afgrænses i denne situation. Annes krop intra-agerer i situationen, og selvom Anne er samarbejdsvillig og ligger roligt, så er hendes æggestokke svært tilgængelige. Presset udefra gør dem modellérbare og konstituerer dem som 'xgdonerende æggestokke', dvs. deres funktion produceres i selve situationen. Annes krops grænser overskrides for en stund i sygeplejerskens intra-aktion gennem berøring, pres og styring af æggestokkens position. Samtidigt intra-agerer forskellige væsker. Morfinen, der skydes ind som en væske i blodbanen, er en bedøvelse, der får Anne til at slappe af og blive lidt svimmel. En anden væske suges ud, nemlig follikelvæsken i ægblærerne (de 'sorte klatter' der tømmes for væske på skærmen), og overføres til det lyserøde medie. Den læskende røde saft vi drikker bagefter markerer afslutningen på xgudtagningen og udfylder en tørhed og et behov for ny energi, der er opstået.

Annes sanselige og kropslige oplevelser er således produceret gennem forskellige intra-aktioner, og på samme tid er Annes kropslige og sanselige oplevelser og reaktioner aktører i situationen. Hendes oplevelse af sine æggestokke - hendes æg - giver mening (makes sense) gennem den specifikke praksis at de tages ud for at blive doneret. Æggestokkene og xggene bliver til som et materielt og kropsligt fænomen gennem den hormonbehandling og xgudtagning, som Anne gennemgår (nålestik i folliklerne i æggestokkene, morfinskudet gennem hånden osv.), hvilket frembringer nye sanselige oplevelser af kropslig bevidsthed. I xgudtagningen bliver æggestokkene til som små marker af $æ g$ - kun tilgængelige for lægen til at blive høstet gennem en specifik klinisk og teknologisk procedure. Frivilligt underkastet denne procedure bliver xggene involveret $\mathrm{i}$ en diskurs af 'kropsligt materielt væv med værdi', og gennem denne specifikke intra-aktion bliver æggene - en del af Annes krop som altid allerede er der - produceret som 'donor-æg' og hendes krop som 'xgdonor-krop'. Hormonbehandlingen og de kliniske procedurer producerer en kropslig og materiel oplevelse af 'at være og at gøre xgdonor', som igen producerer specifikke sociale og diskursive betydninger af fænomenet for aktørerne i dets intra-aktion.

De forskellige sanselige indtryk er sammenfiltret med de forskellige aktører i fænomenet, og på den måde bliver den xgudtagnings-gynækologiske praksis konstitueret som og gennem en kropslig oplevelse hos $x$ gdonoren. En bestemt xgdonor-krop konstitueres, og for ægdonoren konstitueres en specifik kropslig bevidsthed i situationen. Ved at indstille fokus på de sanselige aspekter af begivenheden tydeliggøres, hvordan sanserne og det kropslige gør noget for situationens konstituering af bestemte grænser, kroppe, praksisser og betydninger. Min embodiment i situationen gør, at bevidstheden om kropslige grænser der markeres/overskrides, bliver tydelig, og viser, hvordan Annes kropslige intra-aktion med xgudtagningen gør hendes krop genkendelig som xgdonor-krop, og hvordan 
de uvante og for situationen specifikke sansninger i kroppen er medkonstituerende for den diskursive betydning af hendes $\mathfrak{x g}$ som donor-æg.

\section{KONKLUSION}

De tre begivenheder og min læsning af dem repræsenterer, hvordan materialitet og kropsliged kan udforskes gennem en sanseetnografisk og Barad-inspireret tilgang. Tilsammen viser de tre begivenheder, hvordan gynækologisk praksis og xgdonation kan forstås som sammenfiltringer af teknologikrop-socialitet i de tid-rum-materialiseringsprocesser, som konstituerer fænomenet. De gynækologiske undersøgelsespraksisser, der analyseres, består af konkrete teknologiske og medicinske materialiteter og diskurser og af en bestemt kropslighed og sanselighed. Sammen er de en variation af agenser, der producerer specifikke oplevelser og betydninger.

En sanse-etnografiske tilgang tilbyder her det metodologiske svar på et ønske om at tage materialitet og de måder, materialiteter gør sig selv mærkbare på, alvorligt. Det er netop gennem den auto-etnografiske oplevelse af det specifikke fænomen, at en kropslig viden om de materielle agenser i fænomenet udvikles. De auto- og sanseetnografiske observationer gør gynækologiske praksisser forståelige gennem den kropslige erindring og viden, der er tilstede $i$ alle tre begivenheder. Her forstås den kropslige erindring og erfaring som betydningsskabende for situationen, som sammenfiltret i fænomenet med en fælles social og kulturel forventning til oplevelsen. Disse kropslige beretninger via auto- og sanseetnografiske observationer tydeliggør, at forståelsen af det specifikke fænomen er baseret på og defineret i samspil med de kropslige erfaringer et bestemt fænomen involverer, og hvordan materialitetens agens spiller ind i dette. Min læsning af de tre begivenheder tydeliggør således, hvordan sammenfiltring af sanselige og materi- elle aspekter i fænomenet konstituerer specifikke kroppe, grænser og betydninger.

Koblingen af det baradske syn, at materialitet har agens, og sanse-etnografiens tilgang til sansning som en kropslig (materiel) betydningsskabende viden og agens, producerer en forståelsesramme for de specifikke undersøgte materielle agenser i gynækologiske praksisser og xgdonation. Denne metodologiske ramme åbner op for at forstå, hvordan disse agenser er integrerede $\mathrm{i}$ den sanselige/kropslige oplevelse af at være og at gøre xgdonor, og er medkonstituerende for det specifikke frnomens diskursive betydning.

\section{Noter}

1. Begivenhed et og tre fandt sted i begyndelsen af 2016 på en offentlig dansk fertilitetsklinik. Ægdonation indebærer, at en kvinde gennemgår hormonbehandling i 8-14 dage for at få flere æg til at vokse sig større end i en almindelig cyklus, for derefter at blive taget ud til IVF behandling med henblik på en recipients graviditet. IVF eller in-vitro fertilisation er en type af fertilitetsbehandling, hvor kvindens xgceller tages ud for at blive befrugtet med sædceller i reagensglas, for derefter at blive sat op i kvindens livmoder med henblik på graviditet. 2. Se (Barad 2001) og (Barad 2007, kapitel 5), hvor Barad undersøger forholdet mellem 'det diskursive' og 'det materielle' (agential realism) ved hjælp af ultralydsscanneren, som bruger en piezoelektrisk krystal til at både sende og modtage ultralydsbølger (Barad 2001: 99).

\section{LITTERATUR}

- Adrian, Stine (2006): Nye skabelsesberetninger om ag, sad og embryoner. Et etnografisk studie af skabelser på sedbanker og fertilitetsklinikker. Linköping: Institutionen för Tema - Tema Genus. Linköpings Universitet.

- Alaimo, Stacy \& Hekman, Susan (2008): Introduction: Emerging Models of Materiality in Feminist Theory, i: Stacy Alaimo \& Susan Hekman (eds.): Material Feminisms. Indiana University Press, Bloomington. 
- Almeling, Rene (2011): Sex Cells: The Medical Market for Eggs and Sperm. University of California Press, Berkeley.

- Barad, Karen (2001): Performing Culture / Performing Nature. Using the Piezoeletric Crystal of Ultrasound Technologies as a Transducer Between Science Studies and Queer Theories, in: Christina Lammer (ed.): Digital Anatomy. Verlag Turia + Kant, Wien.

- Barad, Karen (2007): Meeting the Universe Halfway. Quantum Physics and the Entanglement of Matter and Meaning. Duke University Press, Durham.

- Berkaak, Odd Are \& Anne-Katrine Brun Norbye (2014): Sansningens Antropologi - En Tematisk

Og Teoretisk Reorientering, i: Norsk Antropologisk Tidsskrift /3-4.

- Butler, Judith (1993): Bodies that Matter. On the discursive limits of sex. Routledge, New York.

- Christensen, Hilda Rømer \& Bettina Hauge (2012): Feminist Materialisms, i: Kvinder, Køn es Forskning 2012/1-2.

- Christiansen, Lene Bull; Frydendahl, Bolette \& Hee Pedersen, Christina (2013): Vendinger Mod Følelser Og Affekt, i Kvinder, Køn \& Forskning 2013/3-4.

- Colebrook, Claire (2010): Deleuze: A Guide for the Perplexed. Continuum, London.

. Curtis, Anna (2010): Giving 'Til It Hurts: Egg

Donation and the Costs of Altruism, in: Feminist

Formations/22(2).

. Gammeltoft, Tine M. \& Wahlberg, Ayo (2014): Selective Reproductive Technologies, in: Annual Review of Anthropology/43.

- Gupta, Jyotsna Agnihotri \& Richters, Annemiek (2008): Embodied Subjects and Fragmented Objects: Women's Bodies, Assisted Reproduction Technologies and the Right to Self-Determination, in: Journal of Bioethical Inquiry/5(4).

- Haraway, Donna (1988): Situated Knowledges: The Science Question in Feminism and the
Privilege of Partial Perspective, in: Feminist Studies/14(3).

- Haraway, Donna (1997): Modest_Witness ${ }^{\circledR}$ SecondMillenium. FemaleMan@_Meets_OncoMou${ }^{\text {se }}{ }^{T M}$. Feminism and Technoscience. Routledge, New York.

- Harding, Sandra (1986): The Science Question in Feminism: Industrial Policy in Europe. Cornell University Press, Ithaca.

- Hultman, Karin \& Lenz Taguchi, Hillevi (2010): Challenging Anthropocentric Analysis of Visual Data: A Relational Materialist Methodological Approach to Educational Research, in: International Journal of Qualitative Studies in Education/23(5). - Inhorn, Marcia C. \& B. Gürtin, Zeynep (2011): Cross-Border Reproductive Care: A Future Research Agenda, in: Reproductive BioMedicine Online/23(5).

- Leve, Michelle A. (2013): Reproductive Bodies and Bits: Exploring Dilemmas of Egg Donation Under Neoliberalism, in: Studies in Gender and Sexuality/14(4).

- Mol, Annemarie (2002): The Body Multiple: Ontology in Medical Practice. Duke University Press, Durham.

- Nahman, Michal (2008): Nodes of Desire Romanian Egg Sellers, 'Dignity' and Feminist Alliances in Transnational Ova Exchanges, in: European Journal of Women's Studies/15(2).

- Nahman, Michal (2013): Extractions: An Ethnography of Reproductive Tourism. Palgrave Macmillan, London.

- Pink, Sarah (2015): Doing Sensory Ethnography. Sage, London.

- Roberts, Elizabeth F. S. (2012): God's Laboratory: Assisted Reproduction in the Andes. University of California Press, Berkeley.

- Vannini, Phillip; Waskul, Dennis \& Gottschalk, Simon (2012): The Senses in Self, Society, and Culture. A Sociology of the Senses. Routledge, New York. 